\title{
Difference in virulence between Neisseria meningitidis serogroups $W$ and $Y$ in transgenic mice
}

\author{
Lorraine Eriksson ${ }^{1 *}$, Bianca Stenmark1', Ala-Eddine Deghmane², Sara Thulin Hedberg ${ }^{1}$, Olof Säll ${ }^{3}$, Hans Fredlund ${ }^{1}$, \\ Paula Mölling ${ }^{1}$ and Muhamed-Kheir Taha ${ }^{2}$
}

\begin{abstract}
Background: Neisseria meningitidis serogroups $\mathrm{W}$ and $\mathrm{Y}$ are the most common serogroups causing invasive meningococcal disease in Sweden. The majority of cases are caused by the serogroup W UK 2013 strain of clonal complex (cc) 11, and subtype 1 of the serogroup Y, YI strain of cc23. In this study, virulence factors of several lineages within $\mathrm{cc} 11$ and $\mathrm{cc} 23$ were investigated in transgenic BALB/c mice expressing human transferrin. Transgenic mice were infected intraperitoneally with serogroup $W$ and $Y$ isolates. Levels of bacteria and the proinflammatory cytokine CXCL1 were determined in blood collected $3 \mathrm{~h}$ and $24 \mathrm{~h}$ post-infection. Apoptosis was investigated in immune cells from peritoneal washes of infected mice. Adhesion and induction of apoptosis in human epithelial cells were also scored.

Results: The levels of bacteraemia, CXCL1, and apoptosis were higher in serogroup W infected mice than in serogroup $Y$ infected mice. Serogroup $W$ isolates also induced higher levels of apoptosis and adhesion in human epithelial cells. No significant differences were observed between different lineages within cc11 and cc23.

Conclusions: $N$. meningitidis Serogroup W displayed a higher virulence in vivo in transgenic mice, compared to serogroup $Y$. This was reflected by higher bacteremia, proinflammatory activity, and ability to induce apoptosis in mouse immune cells and human epithelial cells.
\end{abstract}

Keywords: Neisseria meningitidis, Serogroup W, Serogroup Y, Transgenic mice, Virulence

\section{Background}

Neisseria meningitidis is a human pathogen that can cause invasive meningococcal disease (IMD), dominated by septicaemia and meningitis, but can also be carried asymptomatically in the throat and nasopharynx [1]. $N$. meningitidis is classified into serogroups, which are differently distributed worldwide $[1,2]$. The bacteria can be further classified into sequence types (ST) by multilocus sequence typing (MLST), where genetically related

\footnotetext{
* Correspondence: lorraine.eriksson@regionorebrolan.se

1 Department of Laboratory Medicine, Faculty of Medicine and Health, Örebro University, Örebro, Sweden

Full list of author information is available at the end of the article
}

isolates are grouped into clonal complexes (ccs), which can consist of different but closely related STs [3]. Invasive isolates usually belong to a few cc, known as hyperinvasive cc. Invasive $N$. meningitidis isolates have been shown to induce apoptosis in epithelial cells [4]. This induction seems to involve several bacterial structures such as the IgA protease, the outer membrane protein porin B (PorB), and the lipooligosaccharide (LOS) [5-7].

N. meningitidis serogroups $\mathrm{W}(\mathrm{NmW})$ and $\mathrm{Y}(\mathrm{NmY})$ are currently the major serogroups causing IMD in Sweden, with incidences (and proportions) of $0.22(44 \%)$ and $0.12(22 \%)$ per 100,000 population respectively in

C C The Author(s). 2020 Open Access This article is licensed under a Creative Commons Attribution 4.0 International License, which permits use, sharing, adaptation, distribution and reproduction in any medium or format, as long as you give appropriate credit to the original author(s) and the source, provide a link to the Creative Commons licence, and indicate if changes were made. The images or other third party material in this article are included in the article's Creative Commons licence, unless indicated otherwise in a credit line to the material. If material is not included in the article's Creative Commons licence and your intended use is not permitted by statutory regulation or exceeds the permitted use, you will need to obtain permission directly from the copyright holder. To view a copy of this licence, visit http://creativecommons.org/licenses/by/4.0/ The Creative Commons Public Domain Dedication waiver (http://creativecommons.org/publicdomain/zero/1.0/) applies to the data made available in this article, unless otherwise stated in a credit line to the data. 
2018. The incidence of NmY has been high in Sweden since 2005, with the increase due to the YI strain of cc23 [8-10]. YI consists of two genetically distinct subtypes, one of which (subtype 1) has been determined as the cause of the increased incidence [9]. An increase in $\mathrm{NmY}$ has also been reported from other European countries [11]. The increased incidence of $\mathrm{NmW}$ is due to strains that are similar to the $\mathrm{NmW}$ UK 2013 strain of cc11 [12]. This strain belongs to the NmW South American/UK sub-lineage of cc11. The sub-lineage consists of three strains: the South American strain, the original UK strain, and the UK 2013 strain (hereafter called the 2013 strain) [13, 14]. An increase in $\mathrm{NmW}$ has been reported from several European countries [14-17], and in 2015, the 2013 strain was involved in an outbreak at an international scout jamboree in Japan, which resulted in invasive cases reported from Scotland and Sweden [13].

The genetic differences within YI cc23 and the South American/UK sub-lineage of cc11 are few, and cannot explain the observed difference in incidence of the subtypes or strains in these serogroups $[9,12]$. However, the impact of these differences on the bacterial virulence has not been explored experimentally. A transgenic $\mathrm{BALB} / \mathrm{c}$ mouse model that expresses human transferrin can be used as a reliable tool to study meningococcal virulence, as it provides bacteria with a human source of iron that is required for bacterial growth. This model allows consistent bacterial growth in blood of infected mice, since meningococci can acquire iron from human transferrin as seen during invasive infection in humans $[18,19]$. The aim of this study was to investigate virulence factors using an experimental pathophysiological comparison between and within $\mathrm{NmW}$ and $\mathrm{NmY}$ isolates that gives an increased incidence of IMD in a defined system using a transgenic mouse model expressing human transferrin.

\section{Results}

Survival of meningococcal isolates in transgenic mice

Transgenic BALB/c mice expressing human transferrin were infected with $\mathrm{NmY}$ and $\mathrm{NmW}$ isolates. The $\mathrm{NmY}$ isolates belonged to YI subtype $1(n=6)$, YI subtype 2 $(n=3)$, and cc23 but not YI ( $n=1$, called cc23 other). The NmW isolates belonged to the original UK strain $(n=3)$ and the 2013 strain $(n=10)$. Four of the 2013 strain isolates were connected to the 2015 World Scout Jamboree in Japan, one was invasive, and the other three were nasopharynx/throat isolates collected from close contacts during the outbreak.

Three hours post-infection, the mice showed slight hypothermia but there were no significant differences between the serogroups. After $24 \mathrm{~h}$ of infection, more pronounced hypothermia was observed in mice infected with $\mathrm{NmW}$ isolates, differing significantly from $\mathrm{NmY}$ infected mice, which showed no hypothermia $(p<0.0001)$. Moreover, mice infected with the NmW 2013 strain invasive isolates showed significantly more hypothermia than those infected with $\mathrm{NmW} 2013$ strain isolates from the nasopharynx/throat $(p<0.01)$ (Fig. 1).

Three hours post-infection, bacteria were detectable in the blood of infected mice. Blood concentrations in terms of colony forming units (CFUs) per ml were significantly higher in NmW infected mice $(n=39)$ than in $\mathrm{NmY}$ infected mice $(n=30)$ after both $3 \mathrm{~h}$ and $24 \mathrm{~h}$ $(p=<0.0001)$ (Fig. 2a). The NmW infected mice had a higher mortality; none of the NmY infected mice died, whereas 15 (infected with two original UK and three 2013 strain invasive isolates) of the $39 \mathrm{NmW}$ infected mice died (Table 1). NmW infected mice had a significant increase in the amount of bacteria after $24 \mathrm{~h}$ compared to $3 \mathrm{~h}(p=0.0105)$.

\section{Induction of the proinflammatory cytokine CXCL1}

The blood collected after infection in mice was also used to investigate levels of the proinflammatory cytokine CXCL1. At both $3 \mathrm{~h}$ and $24 \mathrm{~h}, \mathrm{NmW}$ infected mice showed significantly higher levels of CXCL1 than NmY infected mice $(p<0.0001$, Fig. 2b). No statistical difference was observed between the strains or subtypes of $\mathrm{NmW}$ and $\mathrm{NmY}$.

\section{Induction of apoptosis}

Apoptosis of mouse immune cells was investigated in mice infected with one isolate from each strain or subtype of $\mathrm{NmW}$ and $\mathrm{NmY}$. Within their respective groups, strains of $\mathrm{NmW}$ and the subtypes of NmY did not differ much in terms of the percentage of apoptosis in mouse immune cells recovered from the peritoneal washes (Fig. 3a). However, all NmY isolates induced lower levels of apoptosis than $\mathrm{NmW}$ isolates (Fig. $3 \mathrm{~b}$ ).

One mouse infected with the NmW invasive 2013 strain isolate, PubMLST ID 57576 (P1.5-2, 36-2, F1-1, ST-11) was compared to a non-infected mouse in order to gate the inflammatory cells. Specific fluorescence labelling was employed to detect neutrophils (Ly6G+), monocytes (Ly6C+), and macrophages (F4/80+) in the peritoneal washes. Large recruitments of neutrophils $(\mathrm{Ly} 6 \mathrm{G}+)$ and monocytes (Ly6C+) were detected at the site of infection compared to a non-infected mouse. Moreover, low proportions of these cells underwent apoptosis (7 and 9\%, respectively). Conversely, resident macrophages $(\mathrm{F} 4 / 80+)$ were present in lower proportions in the infected mouse than in the non-infected mouse ( 4 and $13 \%$, respectively). This reduction was correlated with a high level of induction of apoptosis in this macrophage population (98\%) (Fig. 4). 


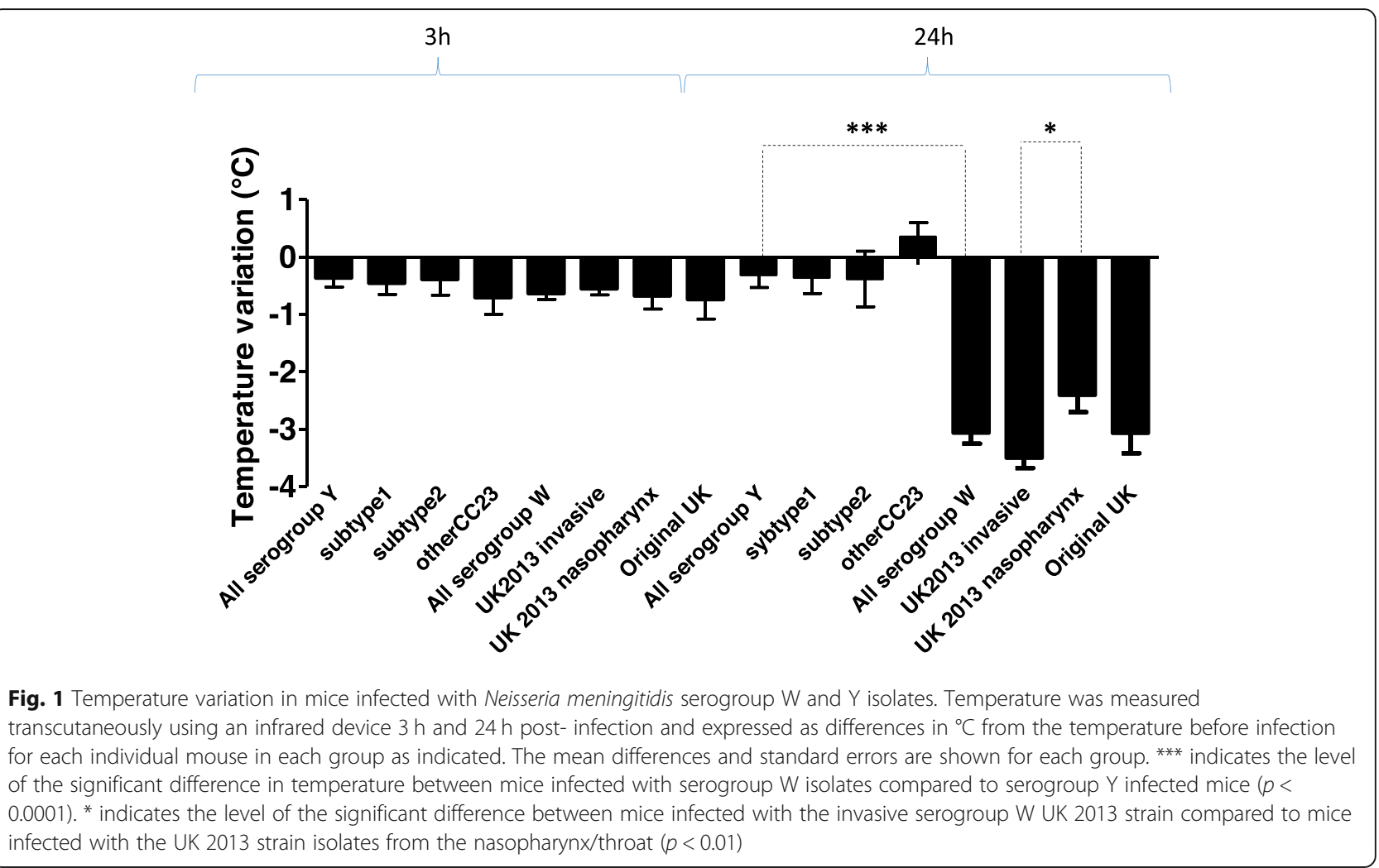

\section{Interaction of meningococcal isolates with human epithelial cell line}

To correlate our results in mice to human infection at the primary site of infection (the epithelial cells), we compared the interaction of $\mathrm{NmW}$ and $\mathrm{NmY}$ isolates with human endometrial carcinoma epithelial cell line Hec-1-B cells. NmW infected cells induced a higher percentage of apoptosis $(p<0.0001)$ (Fig. 5). However, there was no significant difference between the different lineages within $\mathrm{NmW}$ and $\mathrm{NmY}$.

NmY infected cells had few adherent bacteria whilst $\mathrm{NmW}$ infected cells had higher amounts of adherent bacteria (Fig. 6). The difference in adherent bacteria was statistically significant $(p=0.0004)$ (Fig. 7). There was no difference in adherence between lineages in the serogroups.

Genomic analysis and allelic differences in genes involved in apoptosis, inflammatory response, LOS, and iron acquisition

Whole genome sequencing (WGS) data from the NmW and NmY isolates were used to analyse and compare specific genes known to be involved in inflammatory response and induction of apoptosis. The most frequent alleles of iga, porB, ponA, penA, genes involved in iron acquisition (lbpA, lbpB, tbpA, tbpB, hpuA, hpuB, hmbR), and genes encoding LOS ( $m s h A, r l p B, r f a F, \operatorname{lgt} F, r f a K$, $Y h b G, \operatorname{lptC}, \operatorname{lgtE}, \operatorname{lgt} B, \operatorname{lpt} 3, \operatorname{lpt} 6$ and $r f a C)$ are displayed in Table 2. The frequency of these alleles was also examined among all NmW $(n=3040)$ and $\mathrm{NmY}(n=1590)$ isolates present in PubMLST (Table 2). The number of amino acids that differed between the most frequent alleles found in the $\mathrm{NmW}$ and $\mathrm{NmY}$ isolates are also given in Table 2. All NmW isolates had PorB2, and all NmY YI isolates had PorB3 except NmY cc23 other, which had PorB2.

Isolates were investigated for the IgA1 protease (IgaP and Iga $\alpha$ domains) as well as the IgaP domain alone using western blotting and PCR. The whole IgA1 protease (IgaP and Iga $\alpha$ domains) was present in all the $\mathrm{NmW}$ isolates and none of the $\mathrm{NmY}$ isolates, as identified by western blot (Fig. 8a). However, the IgaP domain was present in both $\mathrm{NmW}$ and $\mathrm{NmY}$ (Fig. 8a). The Iga $\alpha$ domains of $\mathrm{NmW}$ and $\mathrm{NmY}$ isolates were compared to a serogroup $\mathrm{B}$ isolate (MC58) by PCR. Serogroups W and Y both had smaller Igaa domains than MC58 (Fig. 8b).

Allelic differences in LOS encoding genes between $\mathrm{NmW}$ and NmY isolates are shown in Table 2. One locus (lpt6) was present in all of the $\mathrm{NmW}$ isolates and none of the NmY isolates; this encodes O-6 PEA LOS transferase that adds phosphoethanolamine (PEA) to the LOS (Table 2). When all NmY isolates $(n=1590)$ in PubMLST were checked, this gene was absent in $96 \%$ of the isolates. The difference in amino acids in LOS genes due to differences in the most 


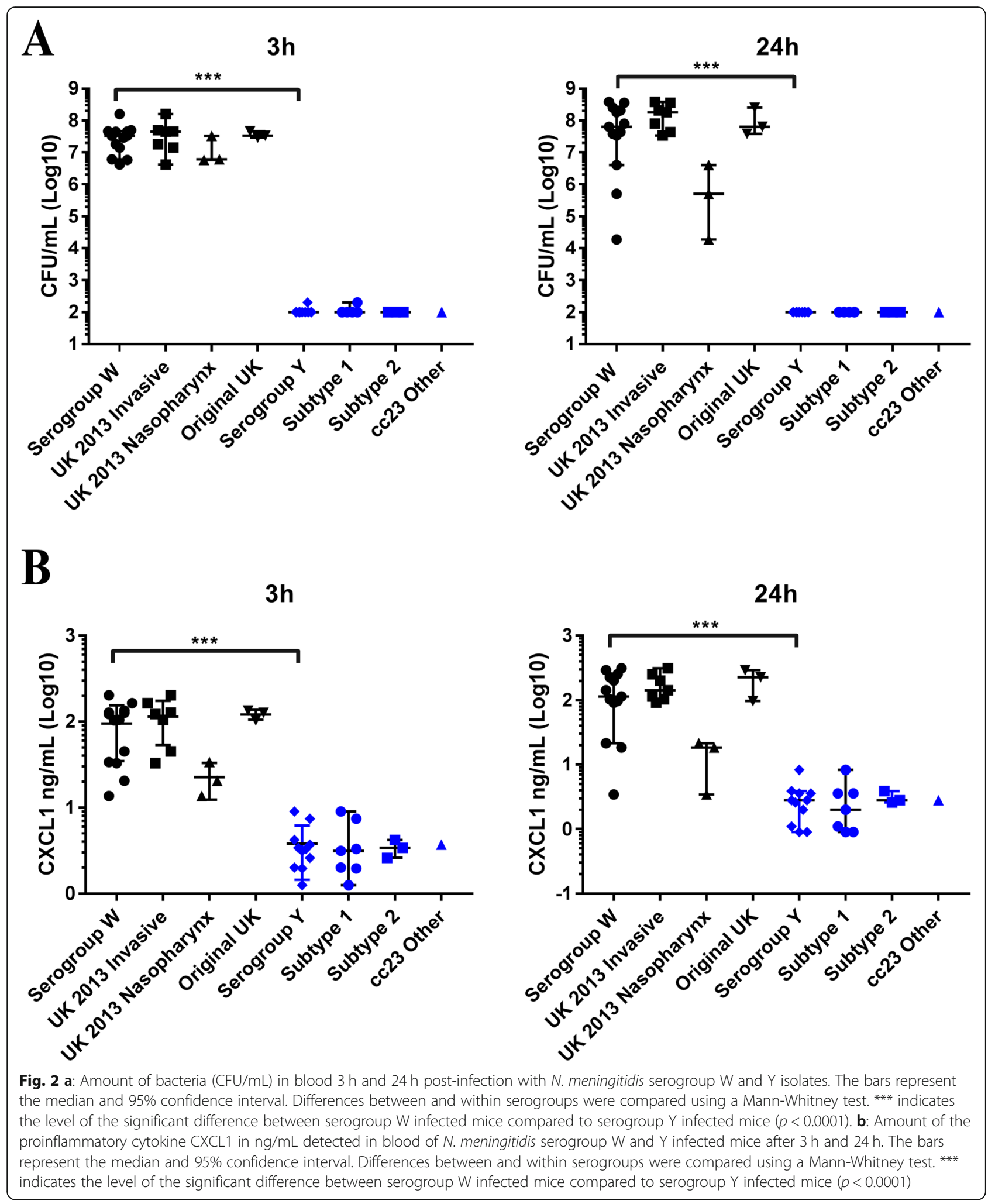

common alleles of $\mathrm{NmW}$ and $\mathrm{NmY}$ is displayed in Table 2.

$N$. meningitidis has several proteins for iron acquisition, including lactoferrin binding proteins $\mathrm{A}$ and $\mathrm{B}$
(NEIS1468, NEIS1469), transferrin binding proteins A and B (NEIS1693, NEIS1691), haemoglobin-haptoglobin utilisation proteins (NEIS1946, NEIS1947), and haemoglobin receptor $(h m b R)$. Genes were compared for the 


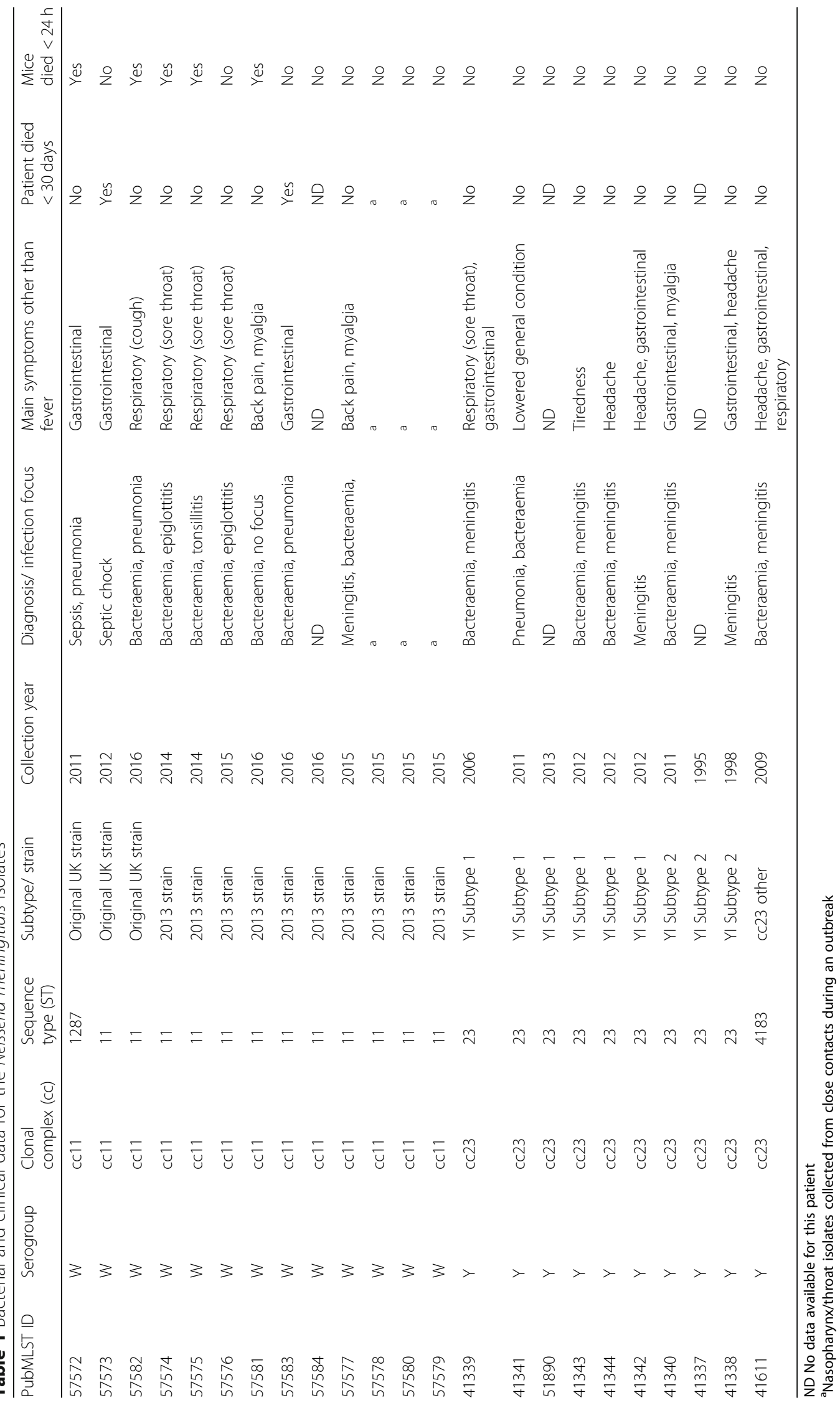




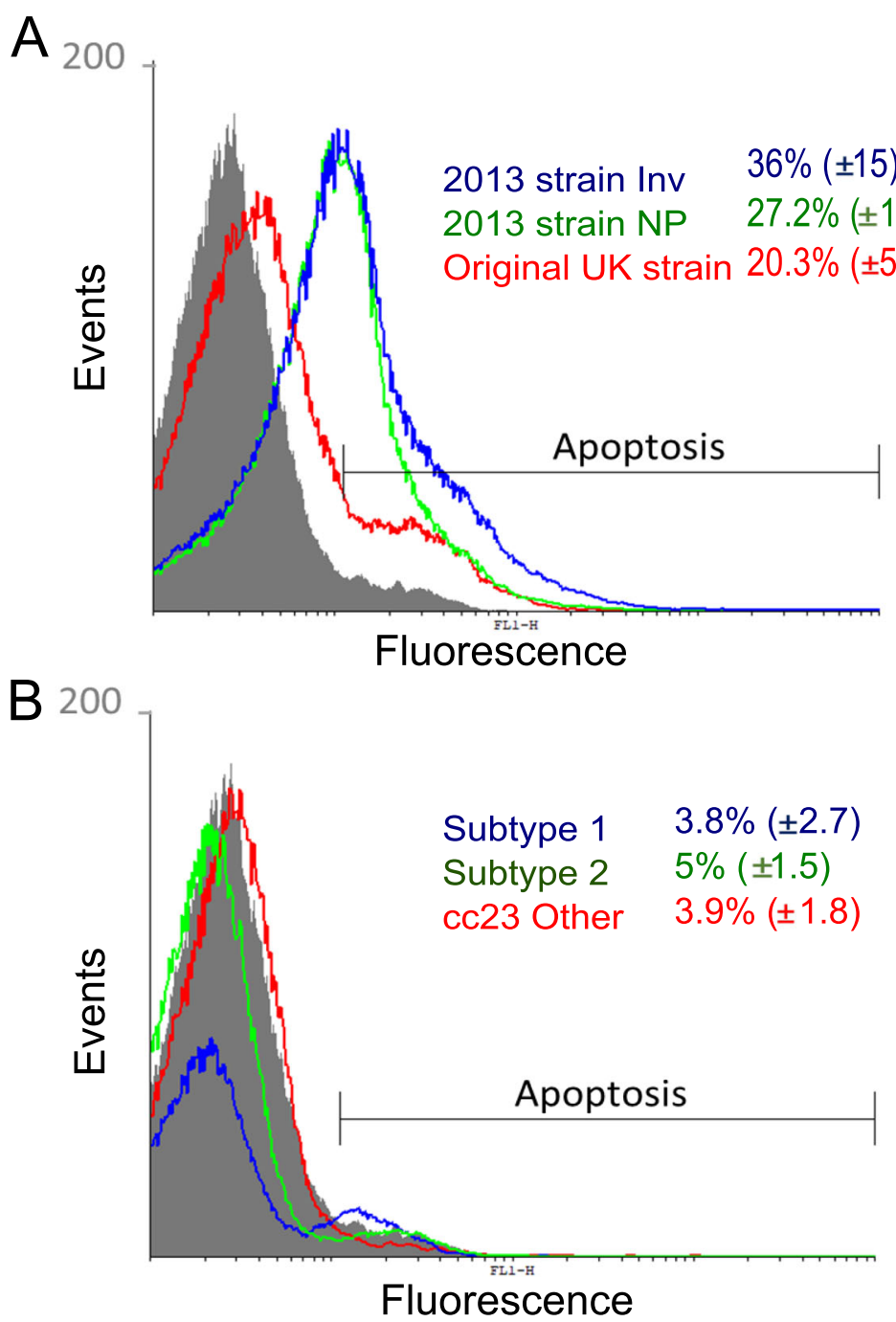

Fig. 3 Histogram overlays of apoptosis of immune cells in the peritoneal washes of infected mice. The apoptosis is displayed as fluorescence levels on the $\mathrm{x}$-axis. Three isolates represent each lineageof the $\mathrm{N}$. meningitidis serogroups. The data from infected mice were compared to data from two non-infected mice as controls. Serogroup W isolates are displayed in histogram a: non-infected mice (grey), original UK isolate (red), invasive 2013 strain isolate (blue), and nasopharynx/throat (NP) 2013 strain isolate (green). Serogroup Y isolates are displayed in histogram b: Yl subtype 1 (blue), Yl subtype 2 (green), cc23 other (red), and non-infected mice (grey). The percentages of cells in apoptosis and standard errors are displayed for each isolate as indicated by the corresponding colours

$\mathrm{NmW}$ and $\mathrm{NmY}$ isolates and the difference in amino acids in these genes in displayed in Table 2. The gene coding for HmbR was missing in the NmY isolates, while it was present in the NmW isolates. When PubMLST was checked, this gene was missing in $98 \%$ of the NmY isolates.

\section{Discussion}

In this study, we propose an approach that allows global comparison of virulence between isolates in close linkage to genotypic characterisation of the isolates. This approach measures the ability to provoke invasive infection in mice and its correlation with the induction of apoptosis at the site of infection as well as the induction of systemic inflammatory response. Using transgenic mice expressing the human transferrin, we were able to show that $\mathrm{NmW}$ isolates were more invasive, were able to provoke death of mice, and induced higher levels of the proinflammatory cytokine CXCL1, when compared to $\mathrm{NmY}$ isolates. We used the intraperitoneal route of infection, which in contrast to the respiratory route is not the natural route of invasive meningococcal infections $[20,21]$ However, the intraperitoneal route in this animal model allows more consistent blood invasion and therefore allows analysis of virulence in terms of ability to grow in blood and spread. Although there were 


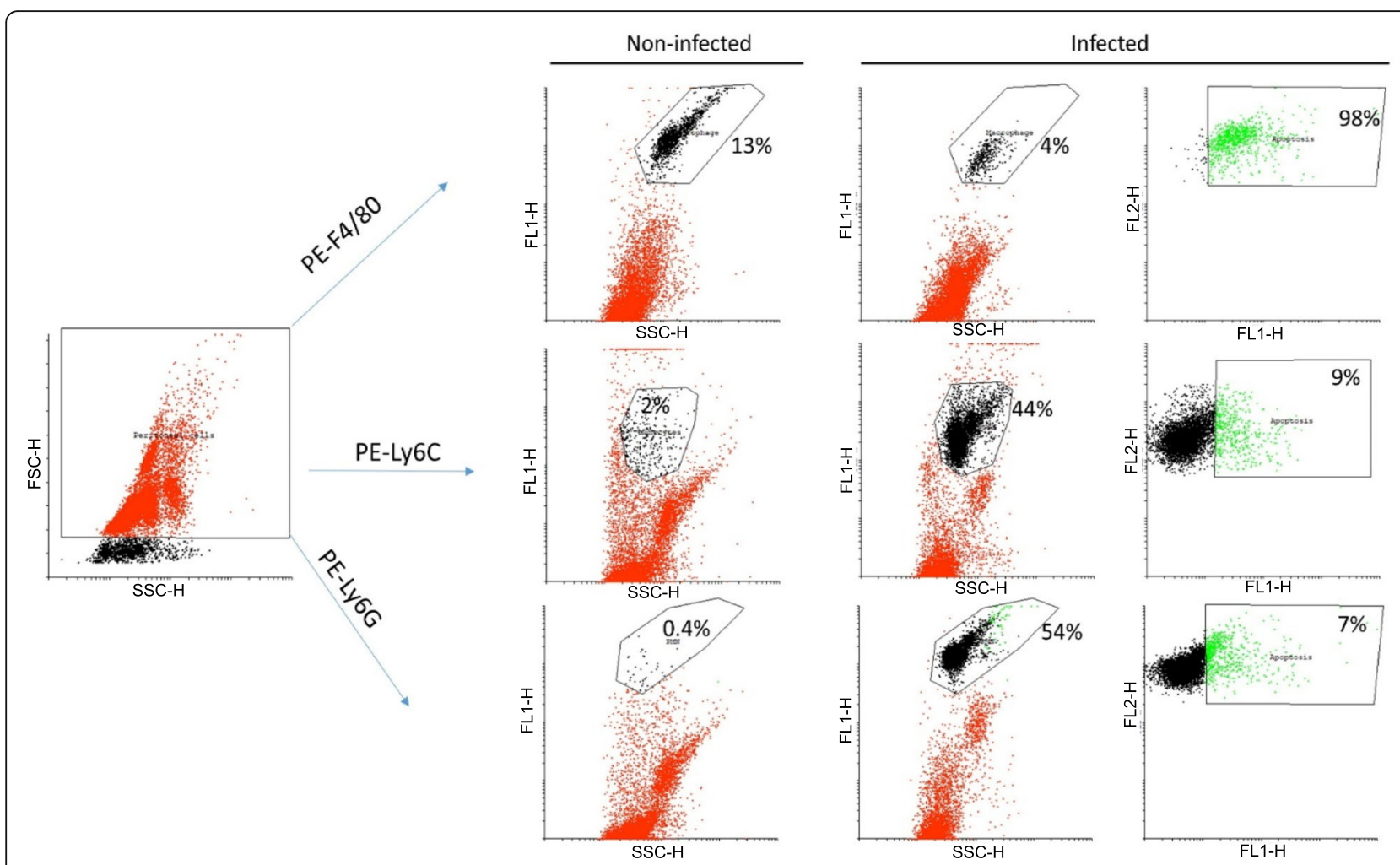

Fig. 4 Staining of immune cells in peritoneal wash from one representative N. meningitidis serogroup W (isolate PubMLST ID 57576) infected mouse, $3 \mathrm{~h}$ post-infection compared to a non-infected mouse. The defined immune cells are gated on the forward (FSC) and scattered (SSC) axis and are seen in red. These cells were then observed according to the specific phycoerythrin (PE) fluorochrome staining (FL2 axis) for macrophages (F4/80+), monocytes (Ly6C+), and neutrophils (Ly6G+), represented in black for both infected and non-infected mice. In the infected mouse, these cells were gated for apoptosis using FITC-labelled Annexin V (FL1 axis), which is represented by green colour. The percentage was calculated for gated cells from all the observed cells, which is indicated in each gate as well as the names of gated cells

significant differences between the serogroups, no significant differences could be detected among the strains or subtypes within each serogroup.

The NmW and NmY isolates used in this study caused both respiratory and gastrointestinal symptoms in humans, with diagnoses and infection foci ranging from tonsillitis and epiglottis to sepsis and meningitis (Table 1). There was, however, no clear connection between the severity of disease in patients and mortality observed in mice. Two of the patients, infected with the original UK and 2013 strains, died within 30 days. Conversely, the mice infected with these isolates did not die within $24 \mathrm{~h}$ of infection.

The NmW invasiveness was associated with higher induction of apoptosis in the inflammatory cells from the peritoneal washes (Figs. 3 and 4). By inducing apoptosis in macrophages and other resident immune cells, bacteria can gain an advantage in survival and spread within the host [22]. The higher levels of apoptosis in human epithelial cells infected with $\mathrm{NmW}$ isolates in comparison to $\mathrm{NmY}$ isolates, as well as higher levels of infection, are in agreement with this hypothesis.
We also investigated genes encoding PorB, penicillin binding protein 1 (PBP1), penicillin binding protein 2 (PBP2), LOS, and IgA1, as these structures can be sensed by host cells as danger signals and may influence the induction of apoptosis. A comparison of the most common alleles within these genes in NmW and $\mathrm{NmY}$ showed that the allelic differences between these serogroups caused changes in several amino acids in each gene (Table 2). All NmW had PorB2; this PorB type has been suggested to be more invasive in previous studies in rats [23, 24], which is in line with our finding of $\mathrm{NmW}$ being more invasive.

Our data suggest that iron acquisition systems differ between the $\mathrm{NmY}$ and $\mathrm{NmW}$ isolates in this sudy (Table 2). This may be linked to the different virulence observed in our mouse model, because the ability to use one of the systems of iron acquisition (the human transferrin) is scored. Interestingly, the haemoglobin receptor protein $(\mathrm{HmbR})$ which has been reported to be linked with enhanced meningococcal virulence [25], was missing in $\mathrm{NmY}$ isolates but present in $\mathrm{NmW}$. This gene was also missing in $98 \%$ of all NmY isolates in PubMLST. 


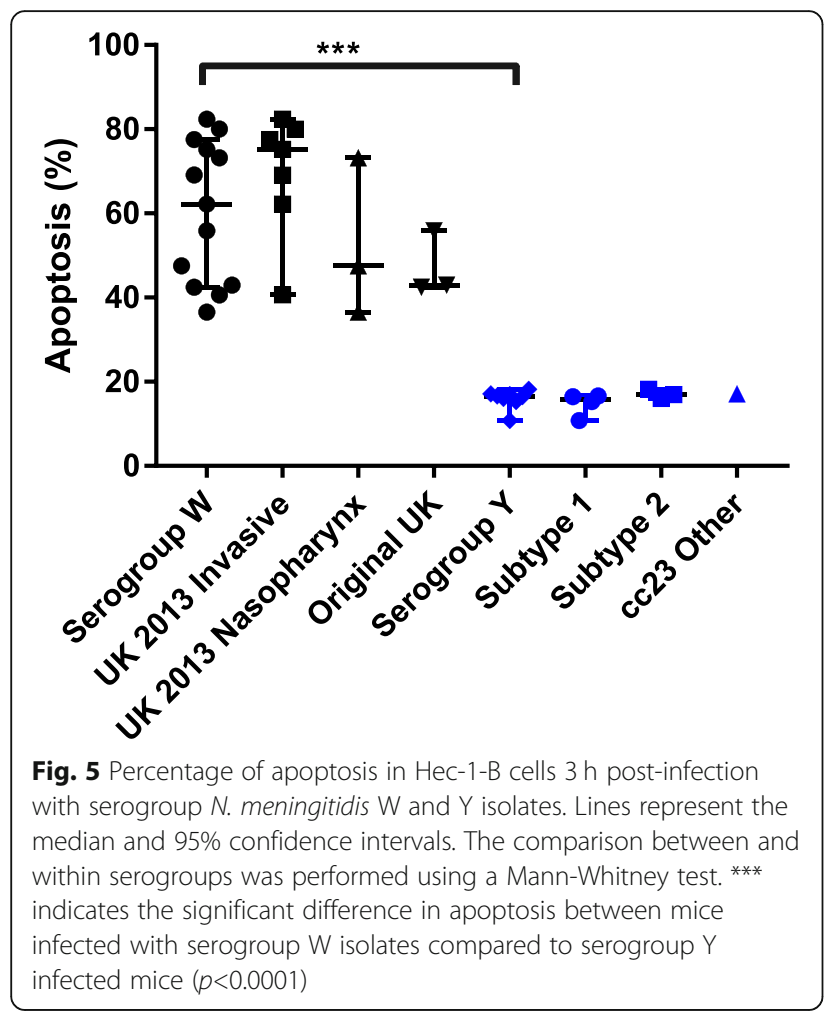

The difference in acquisition of iron by $\mathrm{NmW}$ isolates could enable better growth in the blood and in deep organs such as the spleen. However, meningococcal virulence relies on several virulence factors in addition to iron acquisition.

Invasive cc11 isolates have been connected to a higher ability to induce apoptosis. This is in part due to differences in IgA1 protease [5-7], which can induce apoptosis by entering the nucleus of host cells and interacting with $\mathrm{NF}-\mathrm{kB}[6,7]$. Deletion in the iga gene can affect the size of the produced protein. If the bacteria is producing only the IgaP domain and not the whole IgA1 protease (IgaP and Iga $\alpha$ domains), it will not be able to induce apoptosis [6]. Our results (Fig. 8) from
IgA PCR and Western blotting suggest that the iga alleles harboured by $\mathrm{NmW}$ isolates encode a protein with the nuclear transport signals that seem to be absent in the iga alleles of $\mathrm{NmY}$ isolates. Subsequently the IgA protease function differs between the two types of isolates. The role of the nuclear transport signal in inducing apoptosis has already been suggested [6]. We also observed a higher adhesion by $\mathrm{NmW}$ isolates on epithelial cells, which might allow more efficient delivery of these structures and hence contribute to the difference in virulence compared to $\mathrm{NmY}$ in this study, since adhesion to epithelial cells is the initial step required for colonization and invasion into the bloodstream [20, 21].

$\mathrm{NmY}$ isolates seem to be associated with initial respiratory infections in elderly people where other comorbidities can contribute to the outcome of IMD. Exploring the virulence of these $\mathrm{NmY}$ isolates may require the use of the respiratory route of infection in mice. In the present study, the lpt6 gene encoding O-6 PEA LOS transferase that adds PEA to LOS was absent from the $\mathrm{NmY}$ isolates (Table 2). PEA is recognized by the immune system, leading to bacterial elimination and opsonophagocytosis in the infected host. The absence of O-6 PEA on the NmY isolates may mean that this phagocyte-mediated clearance of bacteria in the respiratory tract is avoided [26]. In line with our findings, 96\% of the NmY isolates in PubMLST lacked this gene.

In future studies, genome-wide association will be performed to investigate differences in genes and how this affects the virulence of the bacteria in a larger collection of NmW and NmY isolates, as well as other serogroups of Neisseria meningitidis.

A limitation of this study is that only a few isolates from each lineage of $\mathrm{NmW}$ and $\mathrm{NmY}$ were included. It is possible that examination of additional isolates in each lineage would make it possible to observe statistically significant differences within the serogroups. In this study, we present allelic differences between the investigated isolates. However, these genetic differences have

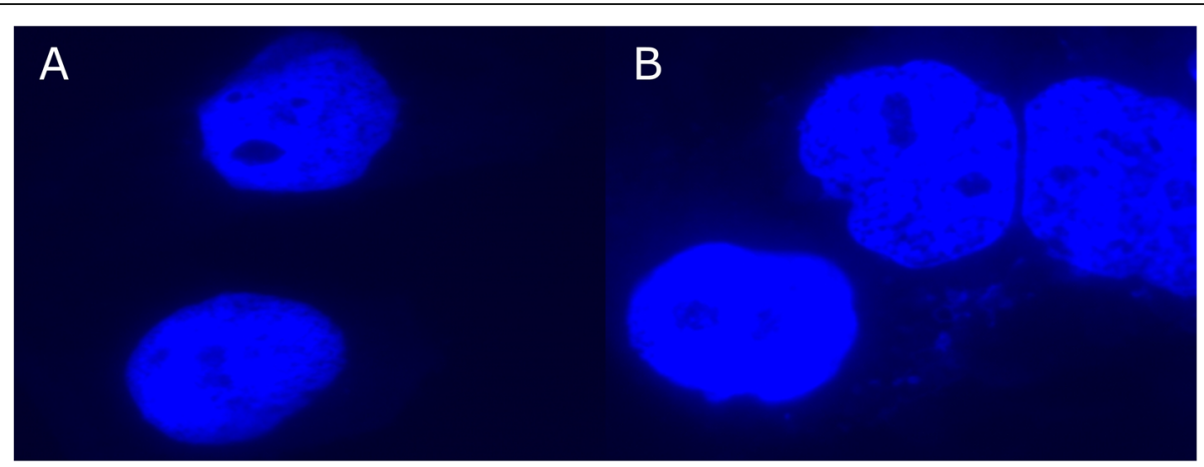

Fig. 6 DAPI staining of Hec-1-B cells. a: Hec-1-B cells infected with a N. meningitidis serogroup Y isolate without adherent bacteria, b: Hec-1-B cells infected with a N. meningitidis serogroup W isolate with adherent bacteria as revealed by DAPI (which stains nucleic acids) 


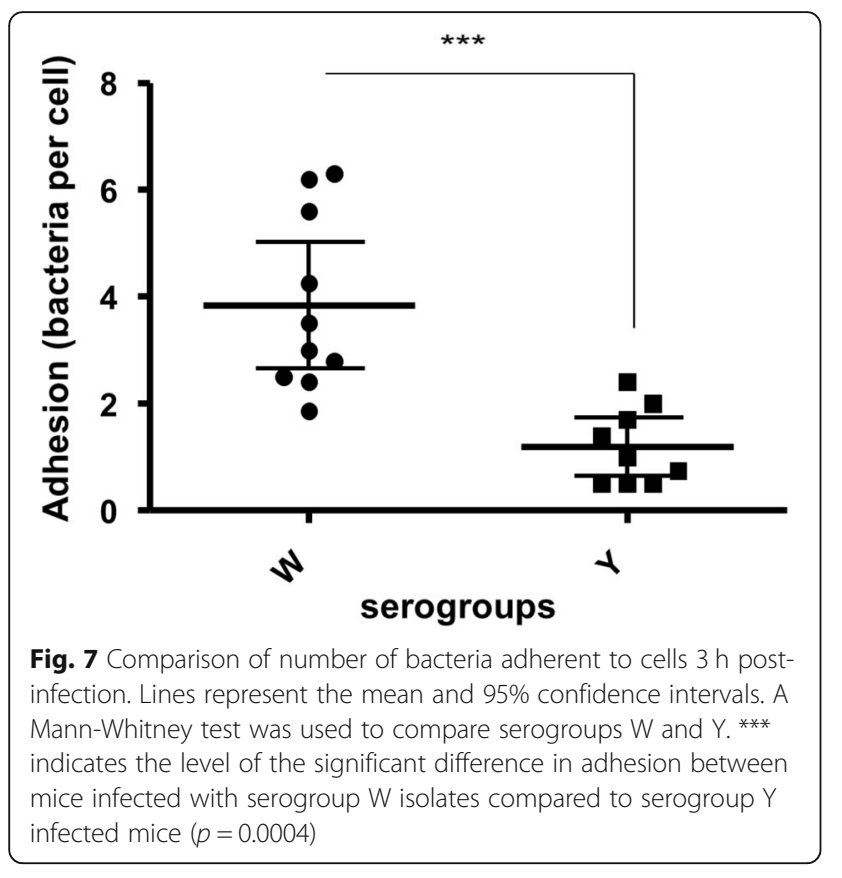

not been experimentally confirmed, which is needed in order to understand how they affect the phenotype.

\section{Conclusions}

This study of NmW and NmY isolates found that the $\mathrm{NmW}$ isolates displayed high virulence in vivo in transgenic mice expressing human transferrin. The low levels of infection and apoptosis seen in NmY do not reflect the number of IMD cases due to this serogroup in Sweden. This study could not explain why specific lineages within these serogroups had a higher incidence than others, and further experiments are required to investigate whether there is a difference in virulence within these serogroups.

\section{Methods}

\section{Bacterial isolates}

Clinical isolates of $N$. meningitidis serogroups $\mathrm{W}(n=$ $13)$ and $Y(n=10)$ collected in Sweden were included in the study (Table 1). Ten of the $\mathrm{NmW}$ isolates belonged to the 2013 strain of cc11, including four isolates connected to the outbreak at the 2015 World Scout Jamboree in Japan (one invasive isolate and three nasopharynx/throat isolates collected from close contacts during the outbreak) [27]. Three invasive isolates belonging to the same linage as the original UK strain were also included (see Additional File 1). Ten NmY isolates of the YI strain of cc23 were included: six of subtype 1 , three of subtype 2 , and one that did not belong to a specific strain of cc23 (called cc23 other; see Additional File 2). Isolates were grown on gonococcal base agar (GCB) solid medium with Kellogg's supplements [28] overnight at $37^{\circ} \mathrm{C}$ with $5 \% \mathrm{CO}_{2}$.
Information regarding diagnoses and mortality of patients infected with the $\mathrm{NmW}$ and $\mathrm{NmY}$ isolates in this study is displayed in Table 1 . Three NmY and one $\mathrm{NmW}$ isolates did not have any patient information available.

\section{Infection in transgenic mice}

The congenic BALB/c transgenic mice expressing human transferrin used in this study were established in the laboratory at the Pasteur Institut (using BALB/c mice from Janvier Labs, France) as previously described [19]. The mice were bred in-house and were kept in a biosafety containment facility in filtertopped cages with sterile litter, water, and food, according to institutional guidelines. This study used transgenic female BALB/c mice with an age of between 8 and 10 weeks and mean weight of $21.7 \mathrm{~g}$. The mice were infected by intraperitoneal injections of $0.5 \mathrm{~mL} \mathrm{NmW}$ and NmY bacterial suspensions of $5 \times 10^{7} \mathrm{CFU} / \mathrm{mL}$. No anaesthesia was used for intraperitoneal injection, as one intraperitoneal injection was considered in our protocol as a low-pain procedure, and we wished to avoid both additional injection and any potential effects on the bacterial infection. Each mouse was infected with one bacterial isolate, and each isolate was used in three separate experiments, requiring a total of 69 mice for the 23 isolates. Blood was drawn from the retro-orbital plexus of infected mice $3 \mathrm{~h}$ and $24 \mathrm{~h}$ post-infection in the laboratory. The blood was then plated, and bacterial count was determined after overnight incubation at $37^{\circ} \mathrm{C}$ with $5 \% \mathrm{CO}_{2}$. Cutaneous temperature was measured using an infrared thermometer (Bioseb) before infection and at $3 \mathrm{~h}$ and $24 \mathrm{~h}$ post-infection, and used to follow the clinical status of the mice during infection, as hypothermia has been reported as a sign of severe meningococcal infection in the mouse model [29]. Results were expressed as mean temperature loss in comparison with temperature before infection.

The experiment design in terms of mortality was reviewed and approved by the Institut Pasteur ethics committee. Our protocol stated that the study would be discontinued/interrupted if weight loss of more than $20 \%$ (not reached) or experimental death of the mouse due to infection occurred. The experiments were conducted for $24 \mathrm{~h}$, at which point blood was drawn for the last time and all animals were euthanized. Health status and overall behaviour of the mice was checked every $6-8 \mathrm{~h}$. It was important for the experiment that the animals were alive for the last blood draw, since blood was only drawn at two time points and a comparison of bacterial load would not have been possible if the animals had been euthanized earlier. Mice were euthanized by cervical dislocation 


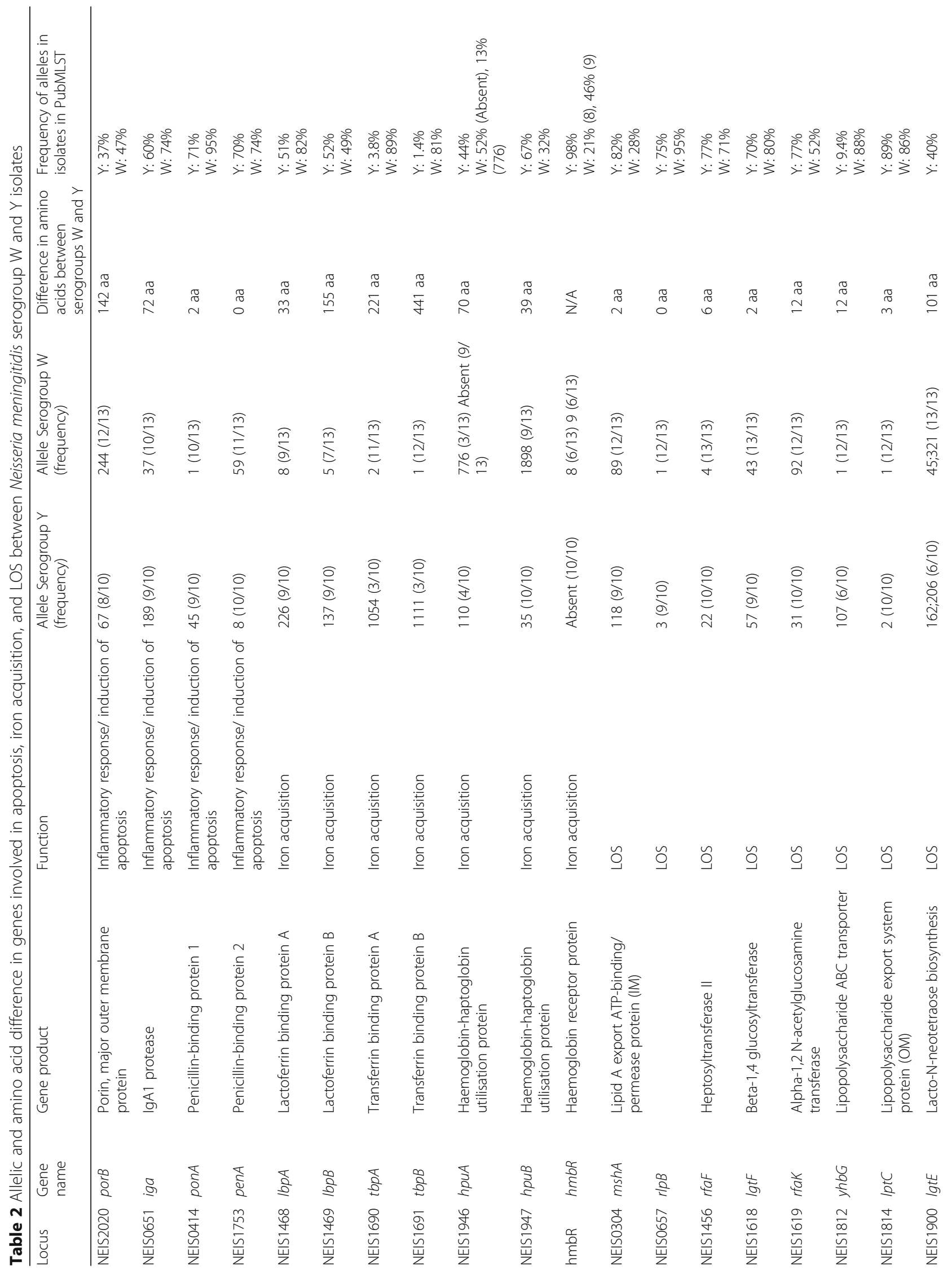




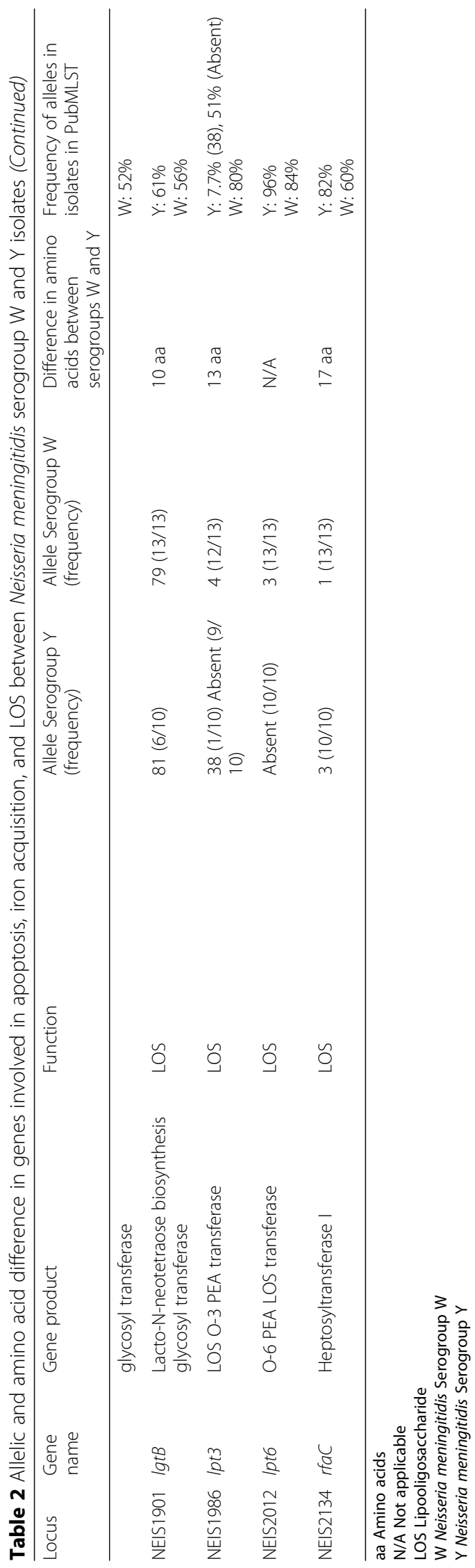




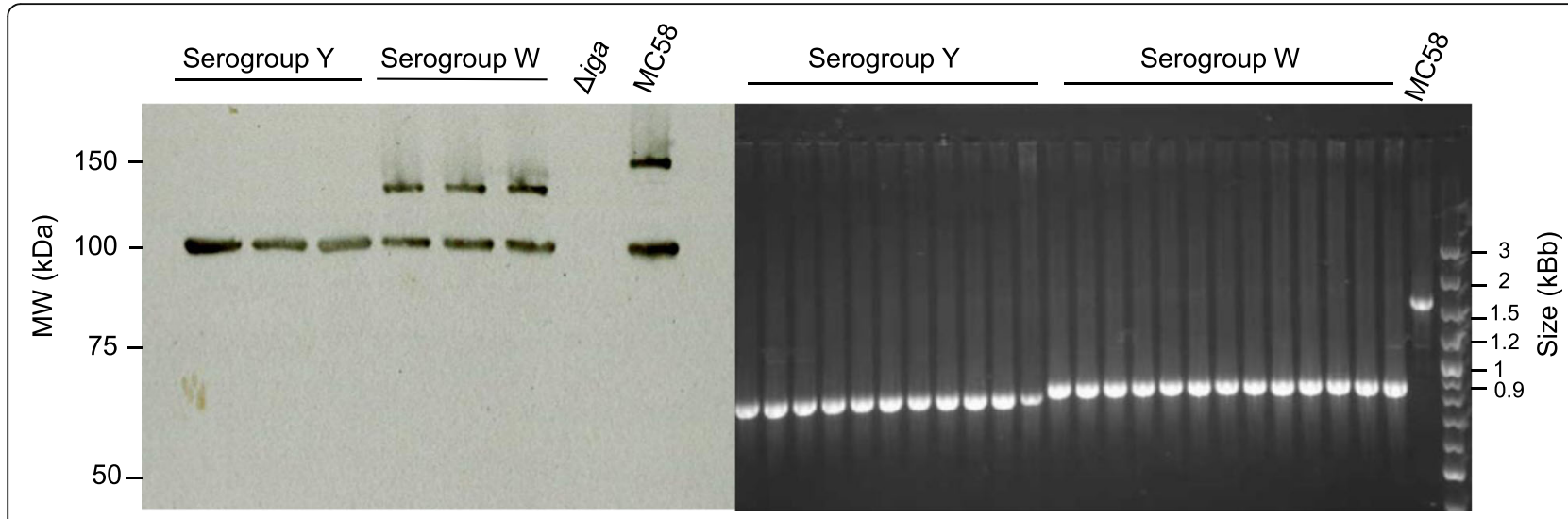

Fig. 8 a: Western blot of IgA1 protease in a collection of serogroup $W$ and $Y$ isolates and compared to a serogroup B isolate (MC58). A mutant strain, $\Delta i g a$, was used as a negative control [6]. The IgA1 protease consisting of the IgaP and Igaa domains generates a protein of size $150 \mathrm{kDa}$ in MC58. An IgA1 protease consisting of only the IgaP domain results in a protein with a size of $100 \mathrm{kDa}$ in MC58. The serogroup W isolates generated a protein that was smaller than $150 \mathrm{kDa}$. b: PCR amplified Igaa domains of serogroup W and $Y$ isolates compared to MC58, which has a complete Igaa domain. The complete lgaa domain of MC58 has a size of approximately $1.5 \mathrm{~kb}$ while the serogroup $\mathrm{W}$ and $\mathrm{Y}$ isolates are smaller, approximately $0.9 \mathrm{~kb}$. The serogroup $\mathrm{Y}$ isolates seem to have a slightly smaller lgaa domain than serogroup $\mathrm{W}$

or by intramuscular injection of high dose of a mixture of $10 \mathrm{mg} / \mathrm{kg}$ xylazine (Bayer, Puteaux, France) and $5 \mathrm{mg} / \mathrm{kg}$ ketamine (Merial, Lyon, France) according to the reviewed protocol. Death was verified when no heartbeat was detected. When mice were euthanized by injection, a cervical dislocation was also performed to ensure that the mice were dead.

\section{Determination of cytokine (CXCL1) levels}

Post-infection with NmW and NmY isolates, blood was collected for analysis of cytokines. The proinflammatory cytokine CXCL1 was chosen as it has previously been shown to clearly and directly reflect the proinflammatory response in this model of systemic meningococcal infection [29]. It is expressed by inflammatory cells such as neutrophils and macrophages, and it has neutrophil chemotactic activity [30]. CXCL1 was measured by ELISA with the Mouse CXCL1/KC kit (R\&D Systems, Minneapolis, MN, US), according to manufacturer's instructions, in serum collected in the laboratory from mice $3 \mathrm{~h}$ and $24 \mathrm{~h}$ post-infection with $\mathrm{NmW}$ and $\mathrm{NmY}$ isolates. Samples were diluted as previously described [31].

\section{Induction of apoptosis in mice at the site of infection}

Mice were infected as mentioned above using bacterial suspensions of $5 \times 10^{7} \mathrm{CFU} / \mathrm{mL}$ with no anaesthesia. Experiments were conducted with one isolate from each lineage of $\mathrm{NmW}(n=3)$ and $\mathrm{NmY}(\mathrm{n}=3)$. Each isolate was used to infect one mouse, and the experiments were repeated three times (total 18 mice). Three hours post-infection in the laboratory, mice were euthanatized by intramuscular injection of a mixture of $10 \mathrm{mg} / \mathrm{kg}$ Xylazine (Bayer) and $5 \mathrm{mg} / \mathrm{kg}$ ketamine (Merial). The peritoneal cavity was washed by injection and subsequent withdrawal of $2 \mathrm{~mL}$ saline. The cells in the peritoneal washes were stained using FITC-Annexin V (Enzo Life Sciences, Farmingdale, NY, USA) at $4{ }^{\circ} \mathrm{C}$ for $30 \mathrm{~min}$ in the dark, as previously described [5]. Apoptotic cells were gated for events showing fluorescent levels higher than the background (10 units on the FL1-H axis), which was determined using unstained cells.

As apoptosis was only observed in mice infected with $\mathrm{NmW}$ isolates (particularly the 2013 strain), we aimed to identify the type of inflammatory cells in the peritoneal washes. A separate experiment of flow cytometry with a FACSCalibur flow cytometer (BD Biosciences, San Jose, CA, USA) was performed as previously described [31]. In brief, we used markers for macrophages (F4/80-PE), neutrophils (Ly6G-PE), and monocytes (Ly6C-PE). Antibodies specific to mouse were purchased from BD Biosciences (Franklin Lakes, NJ, USA). Peritoneal washes of one mouse infected with NmW 2013 strain isolate and one noninfected mouse were performed post-infection in the laboratory. Mice were injected with a high dose of a mixture of $10 \mathrm{mg} / \mathrm{kg}$ xylazine (Bayer) and $5 \mathrm{mg} / \mathrm{kg}$ of ketamine (Merial) prior to the peritoneal wash.

\section{Adhesion to human Hec-1-B epithelial cells}

The human endometrial carcinoma epithelial cell line Hec-1-B was used to evaluate meningococcal adhesion, as it represents a well established and frequently used model of adhesion [32]. In brief, Hec-1-B cells were cultured at $37^{\circ} \mathrm{C}$ in a humidified atmosphere with 5\% $\mathrm{CO}_{2}$ in RPMI 1640 supplemented with 10\% heat-inactivated foetal bovine serum (FBS) (GIBCO, 
Waltham, MA, USA). Infection was carried out with ten $\mathrm{NmW}$ isolates and nine $\mathrm{NmY}$ isolates from each subgroup, at a multiplicity of infection (bacteria to cell ratio) of 10:1. Infection was performed by incubation at $37^{\circ} \mathrm{C}$ for $3 \mathrm{~h}$. After incubation, the cells were stained with DAPI (fluorescent blue nucleic acid staining) and observed under fluorescence microscope (ZEISS Microscopy, Jena, Germany). Viewing and counting of the bacteria was performed with the ZEN imaging software (ZEISS Microscopy). Adhesion was expressed as mean of number of bacteria per cell on the basis of counting 50 epithelial cells.

\section{Analysis and quantitative measurement of apoptosis in human Hec-1-B epithelial cells}

Adhesion was conducted for $3 \mathrm{~h}$ as described above. The cells were stained using FITC-Annexin V and examined as above by flow cytometry with a FACSCalibur flow cytometer (BD Biosciences, USA).

\section{Differences in genes involved in apoptosis, inflammatory response, LOS, and iron acquisition}

Previously published WGS data [33] available on the PubMLST Neisseria database (www.pubMLST.org/neisseria) was used to investigate isolates genetically with $N$. meningitidis cgMLST v1.0 [34]. Neighbour-net networks generated from the genomic comparisons were visualized using SplitsTree4 V4 (www.splitstree.org) [35] (Additional Files 1 and 2). WGS data were also analysed and compared for specific genes known to be involved in inflammatory response and induction of apoptosis using a "gene-by-gene" approach available through the PubMLST Genome Comparator tool of the BIGSdb. The investigated genes were por $B$ (NEIS2020), pon $A$ (NEIS0414), penA (NEIS1753), iga (NEIS0651), genes involved in iron acquisition (NEIS1468, NEIS1469, NEIS1693, NEIS1691, NEIS1946, and NEIS1947), and the genes encoding LOS (NEIS0304, NEIS0657, NEIS1456, NEIS1618, NEIS1619, NEIS1812, NEIS1814, NEIS1900, NEIS1901, NEIS1986, NEIS2012, and NEIS2134). The most frequent alleles of these genes were compared among all $\mathrm{NmY}(n=1590)$ and $\mathrm{NmW}$ $(n=3040)$ isolates in PubMLST (accessed 4 March 2020).

\section{Western blotting and PCR of IgA1 protease}

The IgA1 protease (IgaP and Iga $\alpha$ domains) and the IgaP domain alone were detected using rabbit polyclonal serum against the IgaP protease domain. The SDSPAGE transfer to nitrocellulose was performed as previously described [6]. In brief, immunoreactive bands were visualized using appropriate HRP-conjugated secondary IgG antibody and ECL detection reagents (Amersham Pharmacia Biotech, GE Healthcare, Amersham, UK). A
PCR amplifying the $\alpha$-domain of IgA1 protease was performed as previously described [6] on a selection of $\mathrm{NmW}$ and $\mathrm{NmY}$ isolates.

\section{Statistical analysis}

All experiments were repeated three times and an average calculated for each isolate. The $\mathrm{NmW}$ isolates were separated into the original UK strain, nasopharynx/throat isolates, and the invasive 2013 strain, and the NmY isolates into YI subtype 1, YI subtype 2, and cc23 other. The Mann-Whitney test was used to analyse differences between the serogroups in terms of $\mathrm{CFU} / \mathrm{ml}$ and CXCL1 in mice as well as apoptosis and adhesion in cells. Apoptosis in mouse immune cells was analysed using a t-test. Values of $p<0.05$ were considered statistically significant. When multiple comparisons were performed between isolates in the subtypes or strains of $\mathrm{NmW}$ and $\mathrm{NmY}$, Bonferroni correction was used to correct the $p$-value. The Wilcoxon test was used to compare paired data within serogroups collected at different time points.

\section{Supplementary information}

Supplementary information accompanies this paper at https://doi.org/10. 1186/s12866-020-01760-4.

\section{Additional file 1. Neighbour-net network of Neisseria meningitidis ser- ogroup W isolates included in the study. Coloured dots represent differ- ent years. PubMLST ID is displayed for each isolate in the network. The nasopharynx/throat isolates of the 2013 strain are marked with a star $\left(^{*}\right)$. All isolates were clonal complex 11 except for isolate 57572, which was sequence type 1287 \\ Additional file 2. Neighbour-net network of Neisseria meningitidis ser- ogroup $Y$ isolates from Sweden included in the study. Coloured dots rep- resent different years. PubMLST ID is displayed for each isolate in the network. All isolates were clonal complex 23 except isolate 41611, which was sequence type 4183.}

\section{Abbreviations}

cc: Clonal complex; CFU: Colony forming unit; cgMLST: Core genome multilocus sequence typing; FBS: Fetal bovine serum; IMD: Invasive meningococcal disease; LOS: Lipooligosaccharide; MLST: Multilocus sequence typing; NmW: Neisseria meningitidis serogroup W; NmY: Neisseria meningitidis serogroup Y; PEA: Phosphoethanolamine; PBP1: Penicillin binding protein 1; PBP2: Penicillin binding protein 2; ST: Sequence type; WGS: Whole genome sequencing

\section{Acknowledgements}

Not applicable.

\section{Authors' contributions}

MKT and PM conceived and designed the project. MKT, PM, STH, and HF planned the project. AED, BS, LE, and MKT performed the experiments. MKT, $L E, B S$, and OS summarized the results. MKT and LE drafted the manuscript and performed the statistical analyses. All authors have read and approved the final version of the manuscript.

\section{Funding}

This work was supported by grants from the Örebro County Council Research Committee and Nyckelfonden, Örebro University Hospital, Örebro, Sweden. MKT and AED were supported by the Institut Pasteur, Paris, France. The funders of this study had no role in the study design, data collection, 
analysis, manuscript preparation, or decision to publish. Open access funding provided by Örebro University.

\section{Availability of data and materials}

The genomic data for bacterial isolates analysed during the current study are available in the PubMLST Neisseria database, www.pubMLST.org/neisseria [33]

\section{Ethics approval and consent to participate}

The experiments were approved by the Institute Pasteur review board (2013-0109 protocol 99-174), and the animal work was carried out in accordance with European Union Directive 2010/63/EU (and its revision 86/ 609/EEC). Meningococcal isolates used in this study and their accompanying genetic data were acquired from the National Reference Laboratory for Neisseria meningitidis in Sweden. The collection of clinical data from patients infected with the isolates in this study was approved by the regional ethical review board in Uppsala, Sweden (reference numbers 2018/139 and 2014/ 150).

\section{Consent for publication}

Consent for publication was not needed since the clinical data presented in this study cannot be connected to patients.

\section{Competing interests}

The authors declare that they have no competing interests.

\section{Author details}

${ }^{1}$ Department of Laboratory Medicine, Faculty of Medicine and Health, Örebro University, Örebro, Sweden. ${ }^{2}$ Institut Pasteur, Invasive Infections Unit, Paris, France. ${ }^{3}$ Department of Infectious Diseases, Faculty of Medicine and Health, Örebro University, Örebro, Sweden.

\section{Received: 13 December 2019 Accepted: 23 March 2020}

Published online: 15 April 2020

\section{References}

1. Stephens DS, Greenwood B, Brandtzaeg P. Epidemic meningitis, meningococcaemia, and Neisseria meningitidis. Lancet. 2007:369(9580):2196-210.

2. Rosenstein NE, Perkins BA, Stephens DS, Popovic T, Hughes JM. Meningococcal disease. N Engl J Med. 2001;344(18):1378-88.

3. Maiden MC, Bygraves JA, Feil E, Morelli G, Russell JE, Urwin R, Zhang Q, Zhou J, Zurth K, Caugant DA, et al. Multilocus sequence typing: a portable approach to the identification of clones within populations of pathogenic microorganisms. Proc Natl Acad Sci U S A. 1998;95(6):3140-5.

4. Zarantonelli ML, Lancellotti M, Deghmane AE, Giorgini D, Hong E, Ruckly C, Alonso JM, Taha MK. Hyperinvasive genotypes of Neisseria meningitidis in France. Clin Microbiol Infect. 2008;14(5):467-72.

5. Deghmane AE, Veckerlé C, Giorgini D, Hong E, Ruckly C, Taha MK. Differential modulation of TNF-a-induced apoptosis by Neisseria meningitidis. PLoS Pathog. 2009;5(5):e1000405.

6. Besbes A, Le Goff S, Antunes A, Terrade A, Hong E, Giorgini D, Taha MK, Deghmane AE. Hyperinvasive meningococci induce intra-nuclear cleavage of the NF-KB protein p65/RelA by meningococcal IgA protease. PLoS Pathog. 2015;11(8):e1005078

7. Deghmane AE, El Kafsi H, Giorgini D, Abaza A, Taha MK. Late repression of NF-KB activity by invasive but not non-invasive meningococcal isolates is required to display apoptosis of epithelial cells. PLoS Pathog. 2011;7(12): e1002403.

8. Hedberg ST, Törös B, Fredlund H, Olcén P, Mölling P. Genetic characterisation of the emerging invasive Neisseria meningitidis serogroup $Y$ in Sweden, 2000 to 2010. Euro Surveill. 2011;16(23):19885.

9. Törös B, Hedberg ST, Unemo M, Jacobsson S, Hill DM, Olcén P, Fredlund $H$, Bratcher HB, Jolley KA, Maiden MC, et al. Genome-based characterization of emergent invasive Neisseria meningitidis serogroup $Y$ isolates in Sweden from 1995 to 2012. J Clin Microbiol. 2015:53(7):2154-62.

10. Törös B, Thulin Hedberg S, Jacobsson S, Fredlund H, Olcén P, Mölling P. Surveillance of invasive Neisseria meningitidis with a serogroup $Y$ update, Sweden 2010 to 2012. Euro Surveill. 2014;19(42):20940.

11. Bröker M, Emonet S, Fazio C, Jacobsson S, Koliou M, Kuusi M, Pace D, Paragi M, Pysik A, Simões MJ, et al. Meningococcal serogroup Y disease in Europe: continuation of high importance in some European regions in 2013. Hum Vaccin Immunother. 2015;11(9):2281-6.
12. Eriksson L, Hedberg ST, Jacobsson S, Fredlund H, Mölling P, Stenmark B. Whole-genome sequencing of emerging invasive Neisseria meningitidis serogroup W in Sweden. J Clin Microbiol. 2018;56(4):e01409-17.

13. Lucidarme J, Scott KJ, Ure R, Smith A, Lindsay D, Stenmark B, Jacobsson S, Fredlund $\mathrm{H}$, Cameron JC, Smith-Palmer A, et al. An international invasive meningococcal disease outbreak due to a novel and rapidly expanding serogroup W strain, Scotland and Sweden, July to august 2015. Euro Surveill. 2016;21(45):30395.

14. Lucidarme J, Hill DM, Bratcher HB, Gray SJ, du Plessis M, Tsang RS, Vazquez JA, Taha MK, Ceyhan M, Efron AM, et al. Genomic resolution of an aggressive, widespread, diverse and expanding meningococcal serogroup $B$ $C$ and W lineage J Infect. 2015;71(5):544-52.

15. Bassi C, Taha MK, Merle C, Hong E, Lévy-Bruhl D, Barret AS, Mounchetrou NI. A cluster of invasive meningococcal disease (IMD) caused by Neisseria meningitidis serogroup W among university students, France, February to may 2017. Euro Surveill. 2017;22(28):30574.

16. Russcher A, Fanoy E, van Olden GDJ, Graafland AD, van der Ende A, Kno MJ. Necrotising fasciitis as atypical presentation of infection with emerging Neisseria meningitidis serogroup W (MenW) clonal complex 11, the Netherlands, march 2017. Euro Surveill. 2017;22(23):30549.

17. The Public Health Agency of Sweden. Meningokockinfektion - invasiv. https:// www.folkhalsomyndigheten.se/folkhalsorapportering-statistik/statistik-a-o/ sjukdomsstatistik/meningokockinfektion-invasiv/. Accessed 20 February 2020.

18. Zarantonelli ML, Szatanik M, Giorgini D, Hong E, Huerre M, Guillou F, Alonso JM, Taha MK. Transgenic mice expressing human transferrin as a model for meningococcal infection. Infect Immun. 2007;75(12):5609-14.

19. Szatanik M, Hong E, Ruckly C, Ledroit M, Giorgini D, Jopek K, Nicola MA, Deghmane AE, Taha MK. Experimental meningococcal sepsis in congenic transgenic mice expressing human transferrin. PLoS One. 2011;6(7):e22210.

20. Pizza M, Rappuoli R. Neisseria meningitidis: pathogenesis and immunity. Curr Opin Microbiol. 2015;23:68-72.

21. Taha MK, Deghmane AE, Antignac A, Zarantonelli ML, Larribe M, Alonso JM. The duality of virulence and transmissibility in Neisseria meningitidis. Trends Microbiol. 2002:10(8):376-82

22. Sjölinder M, Altenbacher G, Hagner M, Sun W, Schedin-Weiss S, Sjölinder H. Meningococcal outer membrane protein NhhA triggers apoptosis in macrophages. PLoS One. 2012;7(1):e29586.

23. Lewis LA, Vu DM, Vasudhev S, Shaughnessy J, Granoff DM, Ram S. Factor Hdependent alternative pathway inhibition mediated by porin B contributes to virulence of Neisseria meningitidis. mBio. 2013;4(5):e00339-13.

24. Lewis LA, Vu DM, Granoff DM, Ram S. Inhibition of the alternative pathway of nonhuman infant complement by porin B2 contributes to virulence of Neisseria meningitidis in the infant rat model. Infect Immun. 2014;82(6):2574-84

25. Sevestre J, Diene SM, Aouiti-Trabelsi M, Deghmane AE, Tournier I, François P, Caron F, Taha MK. Differential expression of hemoglobin receptor, $\mathrm{HmbR}$, between carriage and invasive isolates of Neisseria meningitidis contributes to virulence: lessons from a clonal outbreak. Virulence. 2018;9(1):923-9.

26. Mackinnon FG, Cox AD, Plested JS, Tang CM, Makepeace K, Coull PA, Wright JC, Chalmers R, Hood DW, Richards JC, et al. Identification of a gene (Ipt-3) required for the addition of phosphoethanolamine to the lipopolysaccharide inner core of Neisseria meningitidis and its role in mediating susceptibility to bactericidal killing and opsonophagocytosis. Mol Microbiol. 2002;43(4):931-43.

27. Jacobsson S, Stenmark B, Hedberg ST, Mölling P, Fredlund H. Neisseria meningitidis carriage in Swedish teenagers associated with the serogroup W outbreak at the world scout jamboree, Japan 2015. APMIS. 2018;126(4):337-41

28. Kellogg DS Jr, Peacock WL Jr, Deacon WE, Brown L, Pirkle DI. Neisseria gonorrhoeae. I. Virulence genetically linked to clonal variation. J Bacteriol. 1963:85:1274-9.

29. Levy M, Antunes A, Fiette L, Deghmane AE, Taha MK. Impact of corticosteroids on experimental meningococcal sepsis in mice. Steroids. 2015;101:96-102.

30. Moser B, Clark-Lewis I, Zwahlen R, Baggiolini M. Neutrophil-activating properties of the melanoma growth-stimulatory activity. J Exp Med. 1990; 171(5):1797-802.

31. Belkacem N, Bourdet-Sicard R, Taha MK. Lactobacillus paracasei feeding improves the control of secondary experimental meningococcal infection in flu-infected mice. BMC Infect Dis. 2018;18(1):167. 
32. Nassif X, Lowy J, Stenberg P, O'Gaora P, Ganji A, So M. Antigenic variation of pilin regulates adhesion of Neisseria meningitidis to human epithelial cells. Mol Microbiol. 1993;8(4):719-25.

33. PubMLST Neisseria database. https://pubmlst.org/neisseria/. Accessed 14 October 2019

34. Jolley KA, Maiden MC. Automated extraction of typing information for bacterial pathogens from whole genome sequence data: Neisseria meningitidis as an exemplar. Euro Surveill. 2013;18(4):20379.

35. Huson DH, Bryant D. Application of phylogenetic networks in evolutionary studies. Mol Biol Evol. 2006;23(2):254-67.

\section{Publisher's Note}

Springer Nature remains neutral with regard to jurisdictional claims in published maps and institutional affiliations.

Ready to submit your research? Choose BMC and benefit from:

- fast, convenient online submission

- thorough peer review by experienced researchers in your field

- rapid publication on acceptance

- support for research data, including large and complex data types

- gold Open Access which fosters wider collaboration and increased citations

- maximum visibility for your research: over $100 \mathrm{M}$ website views per year

At $\mathrm{BMC}$, research is always in progress.

Learn more biomedcentral.com/submissions 